\title{
ДИДАКТИЧНІ ЧИННИКИ ФОРМУВАННЯ КОМУНІКАТИВНОЇ КОМПЕТЕНТНОСТІ МАЙБУТНІХ ВИКЛАДАЧІВ ЕКОНОМІКИ: ТЕОРЕТИКО-ПРАКТИЧНИЙ АСПЕКТ ПРОБЛЕМИ
}

\begin{abstract}
У статті на основі аналізу, узагальнення, порівняння наукової інформачії скореговано понятійну базу в аспекті окреслення дидактичних підходів і дидактичних принципів, обтрунтовано специфіку обраних методів навчання щзодо формування комунікативної компетентності майбутніх викладачів економіки у прочесі вивчення педагогічних дисииплін.

Ключові слова: комунікативна компетентність, майбутні викладачі економіки, дидактичні підходи, дидактичні принципи, методи навчання.
\end{abstract}

В статье на основе анализа, обобщения, сравнения научной информации скорректирована система понятий в аспекте определения дидактических подходов и дидактических приниипов, обоснована специфика выбраных методов обучения в процессе формирования коммуникативной компетентности будущих преподавателей экономики при изучении педагогических дисииплин.

Ключевые слова: коммуникативная компетентность, будущчие преподаватели экономики, дидактические подходы, дидактические принцииь, методы обучения.

In the article the system of concepts in the aspect of the definition of didactic approaches and principles is corrected on the basis of analysis, synthesis, and comparison of scientific information. Specificity of chosen training methods in the process of communicative competence formation of future teachers of economics at pedagogical disciplines studying is grounded.

Key words: communicative competence, future teachers of economics, didactic approaches, didactic principles, training methods.

Значущим аспектом у формуванні комунікативної компетентності майбутніх викладачів економіки має стати комплекс дидактичних чинників, що потребують розроблення, теоретичного обгрунтування й експериментальної перевірки. Уважаємо за необхідне визначити такі дидактичні підходи, принципи та методи навчання, які відображатимуть специфіку виокремлених компонентів структурно змістової підготовки в економічному виші. Відтак окреслені дидактичні чинники необхідно спрямувати на формування та підвищення рівня сформованості комунікативної компетентності майбутніх фахівців.

Meта cmammi: на основі аналізу розуміння проблеми науковцями визначити дидактичні чинники формування комунікативної компетентності майбутніх викладачів економіки у процесі вивчення педагогічних дисциплін та обгрунтувати їх специфіку.

Оскільки витлумачення поняття «дидактичні умови» щодо окреслення реалізації названих процесів відсутнє, уважаємо за доцільне розкрити його сутність. Зазначимо, що в низці праць натрапляємо на різні визначення. Пор.: 1) обставина педагогічного процесу, яка $є$ результатом цілеспрямованого відбору, конструювання та використання елементів змісту, методів, прийомів, форм навчання для досягнення поставленої мети (В. Андреєв); 2) сукупність об'єктивних можливостей, обставин і заходів освітнього процесу, що структуровано та спрямовано на досягнення мети (В. Ледньов, В. Ляудіс, А. Найн).

Узагальнюючи наведені визначення, пропонуємо розглядати поняття «дидактичні умови»у єдності, взаємозв'язку та взаємодії сукупності обставин, підходів, умов, специфіки дидактичної організації навчального процесу, що сприяють ефективності та результативності формування комунікативної компетентності у процесі вивчення педагогічних дисциплін.

Відповідно до окреслених етапів навчально-пізнавальної діяльності (цільового, мотиваційного, змістового, процесуального, контрольно-оцінного, результативного) визначалися дидактичні умови, в основу яких покладено єдність особистісно зорієнтованого (В. Беспалько, І. Бех, С. Гончаренко, С. Кульневич, Н. Ничкало, О. Пєхота, В. Сєріков, С. Сисоєва, Н. Тализіна, В. Фоменко, I. Якиманська); компетентнісного (М. Авдєєва, В. Байденко, В. Болотов, С. Бондар, І. Гудзик, Н. Дворнікова， І. Єрмаков， Е. Зеєр， І. Зимня， Д. Іванов， Т. Кузьміна， О. Локшина， С. Молчанов, М. Пентилюк， О. Пометун， Д. Равен， О. Савченко, О. Соколова, В. Шадриков); діяльнісного (Б. Ананьєв, Г. Атанов, О. Біляєв, П. Гальперін, О. Спишев, О. Леонтьєв, С. Максименко, А. Маслоу, С. Рубінштейн, Б. Теплов); системного (З. Бакум, О. Горошкіна, С. Гончаренко, К. Гуревич, С. Караман, Ф. Корольов, Н. Кузьміна, В. Кушнір, Г. Кушнір, І. Підласий) підходів у вивченні педагогічних дисциплін у ВНЗ, які реалізовано й експериментально перевірено в контексті нашого дослідження. Суттєвою характеристикою спільності зазначених підходів $\epsilon$ орієнтація на спрогнозовані результати навчання.

Так, особистісно зорієнтований підхід грунтується на принципах пріоритетності та самоцінності студента - суб'єкта навчального процесу; співвіднесенні освітніх технологій із закономірностями професійного становлення особистості; відповідності змісту освіти рівню розвитку майбутньої професійної діяльності; забезпеченні формування професійної компетентності майбутнього фахівця; урахуванні індивідуального досвіду студента та потреб самореалізації, самовизначення, 
саморозвитку. Тому основними функціями постають виховна, розвивальна та самовдосконалення [7, c. 210-211].

Зазначимо, що цей підхід зумовлює встановлення мотивів, усвідомлення мети і завдань навчального процесу, знання способів досягнення мети, оволодіння базовою освітою (стандартом) та виявлення динаміки рівня засвоєння знань, умінь, навичок.

Тому під час вивчення психолого-педагогічних дисциплін доречним є використання освітньозмістових ситуацій, педагогічних зокрема (у процесі вивчення дисципліни «Методика викладання економіки»). Оскільки студент має змогу за штучно створених умов формувати рефлексію власної діяльності, активну позицію на основі здібностей, пізнавальних процесів, нахилів, інтересів та уподобань, відповідно така робота сприятиме розвитку активної мисленнєво-пізнавальної діяльності суб'єктів.

Компетентнісний підхід передбачає взаємозв'язок з особистісно зорієнтованим, за якого чільне місце посідають якості особистості, що розвиваються у процесі навчання. Водночас акцентується увага на особистісній та знаннєвій основах сформованості компетенцій та компетентності. Зауважимо, що основна мета зазначеного підходу - підготовка конкурентоспроможного фахівця зі сформованою системою компетенцій, спроможного до творчого виконання професійної діяльності на рівні світових стандартів. Тому головною умовою реалізації компетентнісного підходу є розроблення системи комунікативної компетентності у процесі вивчення педагогічних дисциплін на основі сформованої мовленнєвої компетентності (аудіювання, читання, говоріння, письмо), що передбачає використання активних методів у поєднанні з індивідуальною формою організації навчання. Тому проведенню практичних, семінарських занять передує попередньо виконане дослідження кожним студентом, за результатами якого розробляються фрагменти вивчення конкретної теми, практичні рекомендації з запровадження досліджуваних аспектів у процес навчальної діяльності. Методична реалізація компетентнісного підходу вимагає використання таких педагогічних засобів, які в освітньому процесі синтезувалися б у здобутті знань, набутті вмінь та способів їх практичної реалізації, де навчальні надбання сприятимуть досягненню мети.

Основною причиною звернення вищої школи до компетентнісного підходу є підвищення вимог до освітньо-кваліфікаційного рівня фахівців, коли результатом має стати не лише здобуття професії, а й формування спроможності успішного здійснення виробничих функцій. Тому поміж тенденцій номенклатури професій та сукупності вимог до компетентності економіста набуває значущості аспект психолого-педагогічної грамотності 3 наданням спеціальності гуманітарного (педагогічного) спрямування. Специфіка освітньої парадигми компетентнісного підходу полягає в тому, що користь отримують індивід (як споживач товару освітніх послуг) і підприємство, у результаті - держава завдяки зростанню конкурентоспроможності національної економіки.

Основним елементом змісту стандартів вищої освіти діяльнісного підходу є об'єкти і знання про них, у контексті якого знання - це результативна діяльність, в основі - активність суб'єкта, що характеризується предметом, потребою, мотивом, метою і завданнями та умовами їх досягнення. Упровадження окресленого підходу в навчальний процес передбачає орієнтацію на спільне розв'язання навчальних завдань за умови активної участі суб'єктів пізнавальної діяльності, у результаті якої студенти самостійно дають відповіді на питання, відкривають закони, аналізують наслідки. Тобто, постають суб'єктами - активними учасниками процесу здобуття знань.

Важливим у контексті дослідження $є$ виокремлення двох компонентів діяльнісного підходу: інформативного (засвоєння якого дає змогу орієнтуватися у надбаннях попередніх поколінь та необхідну «надпрофесійну» підготовку; знання, уміння, навички тлумачаться як об’єкт засвоєння); діяльнісного (опанування якого дозволяє студенту використовувати теоретичні здобутки та «надпрофесійні» знання для розв'язання конкретних виробничих завдань; знання, уміння, навички розглядаються як спосіб діяльності, спрямованої на розвиток творчого потенціалу студента) [5, c. 236].

Інтерес до системності досліджуваних об'єктів є нині однією з основних методологічних настанов у багатьох царинах науки [1, с. 132]. Поняття системного підходу в науковій літературі тлумачиться неоднозначно. Погоджуємося 3 думкою С. Гончаренка, В. Кушнір, Г. Кушнір, що системний підхід передбачає послідовний перехід від загального до часткового за умови чітко визначеної мети; дає змогу реалізувати принципи єдності, розвитку, функціональності, ієрархії, невизначеності, організованості [2, с. 4].

Узагальнені переваги системного підходу, визначені науковцями, зведено й подано у таблиці 1.

Переваги системного підходу (узагальнення аналізу

Таблиия 1 наукових підходів)

\begin{tabular}{|c|l|l|}
\hline \multirow{2}{*}{$№$ 3/п } & \multicolumn{1}{|c|}{ Системний підхід } \\
\cline { 2 - 3 } 2. & $\begin{array}{l}\text { пезультативний ефект упливу на } \\
\text { студента. }\end{array}$ & $\begin{array}{l}\text { Структурувати педагогічний } \\
\text { процес й виокремити складові. }\end{array}$ \\
\hline 2. & $\begin{array}{l}\text { Використання методів дослідження: } \\
\text { аналізу й синтезу. }\end{array}$ & $\begin{array}{l}\text { Здійснювати дослідження в двох } \\
\text { аспектах - диференціації та } \\
\text { цілісності на основі їх } \\
\text { взаємодоповнення. }\end{array}$ \\
\hline
\end{tabular}




\begin{tabular}{|c|c|c|}
\hline 3. & $\begin{array}{l}\text { Вивчення середовища об'єкта } \\
\text { дослідження та визначення його } \\
\text { впливу на цей об’єкт. }\end{array}$ & $\begin{array}{l}\text { Виокремити об'єкт дослідження } \\
\text { та встановити зв'язки на основі } \\
\text { взаємодії з середовищем. }\end{array}$ \\
\hline 4. & $\begin{array}{l}\text { Можливість відсутності стандартного } \\
\text { розв’язання проблем за наявності } \\
\text { нестандартного пошуку нових. }\end{array}$ & $\begin{array}{l}\text { Розробки процедур прийняття } \\
\text { узгодженості об'єктивного та } \\
\text { суб'єктивного розв'язання, } \\
\text { формулювання системи } \\
\text { евристичних правил окреслення } \\
\text { смислово-семантичного простору } \\
\text { досліджуваного педагогічного } \\
\text { процесу. }\end{array}$ \\
\hline 5. & $\begin{array}{l}\text { Вироблення системи евристичних } \\
\text { правил дослідження. }\end{array}$ & $\begin{array}{l}\text { Пошуку шляхів досягнення мети } \\
\text { задля реалізації створеної } \\
\text { логічної системи. }\end{array}$ \\
\hline
\end{tabular}

Отже, вважаємо, справедливим є твердження щодо набуття конкретного змісту досліджуваного процесу відповідно до поглядів науковців, переконань та аспектів взаємозв'язку 3 системою дидактичних принципів за умови їх практичної реалізації.

На нашу думку, системний підхід передбачає логічну послідовність і наступність формування змісту педагогічних дисциплін, використання різноманітних форм і методів навчання у процесі їх вивчення, а також поєднання загальноекономічної підготовки фахівців із психолого-педагогічною підготовкою майбутнього викладача економіки.

Відповідно, постає необхідність визначення завдань, пов’язаних 3 організацією навчального процесу, підвищенням якості викладання, упровадженням сучасних підходів навчання, удосконаленням психолого-педагогічної підготовки фахівців вищої економічної кваліфікації; розвитком системи підготовки фахівців за додатковими спеціальностями (формування індивідуального навчального плану); установленням системи конструктивних відносин науковопедагогічного та студентського колективів; психолого-педагогічним забезпеченням адаптивних процесів.

Реалізація будь-якого підходу передбачає логічну системність вибору відповідних принципів. Нині класифікація принципів здійснюється по-різному, що відображає складність і багатовимірність сучасного педагогічного знання та несформованість категоріального й понятійно-концептуального апаратів педагогіки.

Науковці (Ю. Бабанський, А. Дістервег, Я. Коменський, Ч. Купісевич, В. Оконь, І. Підласий, М. Скаткін, К. Ушинський), розв’язуючи проблеми дидактичних принципів, «виходили 3 необхідності раціонального використання цінного і прогресивного з минулої, сучасної вітчизняної та зарубіжної педагогіки» [1, с. 140].

У сучасній дидактиці єдина номенклатура принципів навчання відсутня. Автори визначають різну кількість, іноді розглядають принципи парами, щоб повніше показати взаємозв'язок головних положень дидактики, розуміючи зміст по-різному [6, с. 104]. Акцентуємо увагу на окремих принципах навчання, співвідносних 3 окресленими вище підходами процесу формування комунікативної компетентності майбутніх викладачів економіки під час вивчення педагогічних дисциплін, дієвих в аспекті нашого дослідження, оскільки кожен із них має свою специфіку. 3 огляду на зазначене доцільно вказати на сутність деяких із них: принции науковості (вимагає відображення у змісті освіти сучасних науково-ймовірних знань; використання в діяльності викладача найновіших досягнень науки та передового досвіду); принцип доступності в поєднанні з високим рівнем складності (вимагає врахування вікових та індивідуальних особливостей студентів); принuип зв'язку теорії з практикою (передбачає використання завдань, пов'язаних із реальними проблемами); принции розвивального навчання (вимагає використання пізнавальних і проблемних завдань, які формують уміння логічного мислення, узагальнення, аналізу); приничи наочності (потребує залучення до сприйняття всіх органів чуття через використання наочних засобів); принцип системності та послідовності (вимагає логічної послідовності у викладі системи взаємозалежних знань); принциип міц̧ності (сприяє усвідомленню засвоєних знань та навичок); принции самостійності й активності (полягає в створенні сприятливих умов для виявлення пізнавальної самостійності й творчої активності) (Ю. Бабанський, С. Гончаренко, Л. Занков, Я. Коменський, I. Лернер, Н. Мойсеюк, В. Онищук, М. Скаткін та інші).

Окреслюючи систему принципів дидактики економічного вишу, слід ураховувати те, що процес навчання має свою специфіку, грунтуючись на філософській рефлексії, діалектиці безперервності та дискретності, єдності кількісних та якісних моментів процесу розвитку. Тому на формування майбутнього фахівця впливає єдність програмного змісту освіти, інтелектуально-творча діяльність $і$ самоосвіта студента. Відповідно, економісти вчаться здобувати знання, вміння та досвід пізнавальнотворчої самостійності за умови формування психологічної, теоретичної та практичної готовності до інтелектуальної діяльності.

Окрім принципів, що усталилися в методиці викладання педагогічних дисциплін, пропонуємо запровадити принцип бінарності, що зумовлює у процесі засвоєння дисциплін психологопедагогічного циклу закладання підвалин майбутньої професійної діяльності в царині економіки та забезпечення необхідної підготовки викладача економіки. Підгрунтям реалізації зазначеного принципу в економічному ВНЗ є спорідненість структури психолого-педагогічних завдань економіки 
і процесу викладання (суб’єкти діяльності, мотиви, цілі, планування, організація, процес дії, предмет, продукт, контроль, результат, засоби, умови, комунікації, прийняття рішення). Як зазначає Л. Грущенко, «реалізація принципу бінарності забезпечує фундаменталізацію підготовки економістів за рахунок знань психології та педагогіки і водночас підготовку до викладання економіки» [3, с. 71].

На нашу думку, до загальнометодичних принципів, які сприяють формуванню комунікативної компетентності майбутнього викладача економіки, необхідно додати ще й такі: цілеспрямованості, індивідуалізації, динамічності.

Виокремлюючи принцип цілеспрямованості, маємо на меті формування результату (упровадження знань, умінь, навичок, способів практичної професійної діяльності). Принцип індивідуалізації вимагає врахування індивідуальних якостей особистості у процесі використання варіативних форм взаємодії у розв'язанні завдань, пам'ятаючи про особливості психічного розвитку студентського віку. Реалізація принципу динамічності здійснюється в єдності особистісних якостей, способів діяльності та їх зміни.

До специфічних принципів пропонуємо додати текстоцентричний (вивчення педагогічних дисциплін на текстовій основі), який передбачає визнання тексту як найважливішої одиниці, «адже в контексті реалізується семантика мовних одиниць усіх рівнів». У зв'язку з цим 3. Бакум зазначає: «Текст - основний засіб оволодіння мовленнєвою діяльністю в усіх іï видах (читання, говоріння, аудіювання, письмо), на його основі формується комунікативна компетенція; текст є засобом створення ситуацій, на грунті яких здійснюється реальне спілкування» [1, с. 142].

У загальній структурі мовленнєвої діяльності всі види (читання, говоріння, аудіювання, письмо) розглядаються як основа взаємодії у процесі спілкування. У межах діяльності мовленнєва дія співвідноситься 3 поняттям «уміння», яке дидакти розуміють як здатність свідомого й творчого застосування набутих знань у певних умовах $[4$, с. 97].

Слушною є думка Л. Грущенко, яка наголошує на підготовці фахівця відповідно до сучасних вимог та сприянні формуванню комунікативної компетентності, необхідності активізувати визначення методологічних $\mathrm{i}$ теоретичних основ педагогічної освіти, удосконаленні системи професійної підготовки через оновлення змісту навчання [3, с. 77-78]. Згідно з виокремленими аспектами дослідження проблеми нами доведено ефективність використання активних, зокрема проблемних (проблемного викладання, частково-пошукового, дослідницького) та ігрових (ділова навчальна гра, дискусія) методів навчання поряд із традиційними (сутність яких достатньо досліджена науковцями).

Наприклад, метод дискусії використовується в навчальній діяльності задля залучення студентів до спілкування у формальних умовах через обмін думками, поглядами на суть пропонованої до розгляду проблеми; дає змогу формувати вміння самостійного мислення та аргументованого викладу думок.

Часто метод ділової гри у процесі вивчення «Методики викладання економіки» використовується під час захисту розроблених проектів фрагментів уроків 3 економіки, особливо напередодні проходження студентами-економістами педагогічної практики.

Організація семінарських занять методом дискусії сприяє зростанню інтересу до педагогічних та економічних наук, учить критично сприймати прочитане, на основі зіставлення різних позицій аргументовано доводити позицію щодо розв'язання досліджуваної проблеми.

Як переконує досвід роботи в економічному виші, ігрова ситуація посилює емоційнопсихологічний стан майбутніх фахівців, збуджує внутрішні стимули активної участі в навчальнопізнавальному процесі здобуття знань, умінь, навичок.

Важливою умовою підвищення ефективності методів навчання $є$ їх діалогічність, що забезпечує процес засвоєння знань. Значущим аспектом взаємопорозуміння $є$ обмін думками і знаходження спільної мови у процесі педагогічного спілкування, що можливе за умови сприяння діалогічності навчального процесу. Адже уміння вступати в діалог та підтримувати його - найважливіше комунікативне уміння, яке сприяє пожвавленню пізнавального інтересу, активізує навчальну діяльність та підвищує ефективність роботи з розвитку мовлення студентів.

Діалогічність процесу засвоєння знань студентами-економістами передбачає врахування таких аспектів: формування питань проблемного характеру; актуальність досліджуваного аспекту; розв’язання проблем здійснюється через діалог різних позицій; навчальний діалог - процес адекватної актуалізації логічного мислення. Тому саме діалог допомагає розкрити творчий потенціал студента завдяки самостійному пошуку істини. Відповідно, діалогічність навчального процесу засвоєння знань має грунтуватися на певних принципах: вибір цікавої й практично важливої ситуації; колективно-консультаційна роль викладача; урахування інтересів та можливостей студентів.

Виходячи зі сказаного вище, визначаємо комплекс дидактичних умов формування комунікативної компетентності майбутніх викладачів економіки, до яких відносимо такі:

- єдність аспектів взаємозв'язку використання дидактичних підходів (особистісно зорієнтованого, компетентнісного, діяльнісного, системного) у контексті суб'єкт-суб'єктної взаємодії учасників навчально-пізнавальної діяльності;

- зумовленість обраних методів окресленим принципам навчання відповідно до етапів навчально-пізнавальної діяльності; 
- забезпечення діалогічності процесу засвоєння знань із педагогічних дисциплін майбутніми викладачами економіки.

Отже, підхід до організації формування комунікативної компетентності 3 урахуванням виокремлених дидактичних умов сприятиме розвитку пізнавального інтересу студентів економічного вишу - майбутніх викладачів економіки.

Названі аспекти покладено в основу розробленої моделі формування комунікативної компетентності майбутніх викладачів економіки у процесі вивчення педагогічних дисциплін, ефективність і доцільність якої підтверджено результатами проведеного експерименту. Комплексне їх використання надасть змогу досягти сформованості комунікативної компетентності у студентів під час навчання та водночас передбачатиме зростання їх навчально-пізнавальної активності.

\section{Література}

1. Бакум 3. П. Теоретико-методичні засади навчання фонетики української мови в гімназії : [монографія] / 3. П. Бакум. - Кривий Ріг : Видавничий дім, 2008. - 338 с. 2. Гончаренко С. Методологічні особливості наукових поглядів на педагогічний процес / Гончаренко С., Кушнір В., Кушнір Г. // Шлях освіти. - 2008. - №4. - С. 2-10. 3. Грущенко Л. М. Формування професійно-орієнтованого ставлення до дисциплін психолого-педагогічного циклу у студентів економічного університету : дис. ... канд. пед. наук : 13.00 .04 / Людмила Миколаївна Грущенко. - К. : Академія педагогічних наук України, 2007. - 240 с. 4. Демидчик Г. С. Психологопедагогічний аспект комунікативно-мовленнєвих умінь / Г. С. Демидчик // Вісник Глухівського державного педагогічного університету. Серія : Педагогічні науки. - Вип. 8. - Глухів : ГДПУ, 2006. - 278 с. 5. Іванченко Є. А. Формування професійної мобільності майбутніх економістів у процесі навчання у вищих навчальних закладах : дис. ... канд. пед. наук : 13.00.04 / Євгенія Анатоліївна Іванченко. - Одеса : Південноукраїнський державний педагогічний університет ім. К. Д. Ушинського, 2005. - 262 с. 6. Лекції 3 педагогіки вищої школи : [навч. посіб.] / за ред. В. І. Лозової. - Харків : «ОВС», 2006. - 496 с. 7. Фіцула М. М. Педагогіка вищої школи : [навч. посіб.] / М. М. Фіцула. - К. : Академвидав, 2006. - 352 с. 